\title{
Влияние лазерной засветки на распознавание объектов оптико-электронными системами на основе ИК матричных фотоприемных устройств
}

\author{
Д.С. Конради ${ }^{1}$, М.В. Сахаров ${ }^{2}$, В.Г. Средин ${ }^{1}$, И.В.Кузнецов ${ }^{1}$ \\ ${ }^{I}$ Военная академия РВСН им. Петра Великого, 143900, г. Балашиха Московской области, \\ ул. Карбышева, 8 \\ ${ }^{2}$ 12ЦНИИ МО РФ, 141307, г Сергиев Посад Московской обл .,ул. Весенняя,26 \\ E-mail:demon125@inbox.ru
}

DOI 10.34077/RCSP2021-44

Значительное число как экспериментальных, так и теоретических работ посвящено исследованию влияния лазерной засветки на ИК оптико-электронные системы (ОЭС) на основе ИК матричных полупроводниковых фотоприемных устройств (МФПУ) [1-4]. Наибольшее внимание уделяется рассмотрению ситуации, когда лазерный источник находится в поле оптической системы $[4,5]$. При этом излучение фокусируется на относительно небольшом числе элементов МФПУ, причем возможны случаи, когда часть этих элементов полностью выводится из строя [5]. В работах $[2,3]$ рассмотрено влияние внеполевой засветки, когда лазерный источник находится вне поля зрения оптической системы ОЭС, а его воздействие обусловлено засветкой излучением, рассеянным на элементах конструкции оптического тракта. Рассеянное излучение воспринимается МФПУ как изменение яркости фона, т.е. дополнительным шумовым сигналом, что приводит к снижению удельной обнаружительной способности фотоприемников. Отметим, что при внеполевой засветке воздействию может подвергнутся относительно большее число пикселей МФПУ, а сама засветка может носить неоднородный характер.

В ряде ОЭС для распознавания объектов применяются корреляционные алгоритмы, с помощью которых производится сопоставление построенного изображения с заданным шаблоном с учетом яркости отдельных формирующих его пикселей. При дополнительной засветке указанных пикселей возможен сбой или срыв идентификации, распознавания или классификации объекта. Для оценки возможностей указанных алгоритмов в условиях внеполевой засветки была разработана соответствующая модель стандартного изображения разнородного подстилающего фона с размещенными на нем различными геометрическими фигурами [4], в которой в зависимости от угла падения лазерного излучения на входную апертуру ОЭС и его мощности изменялось количество

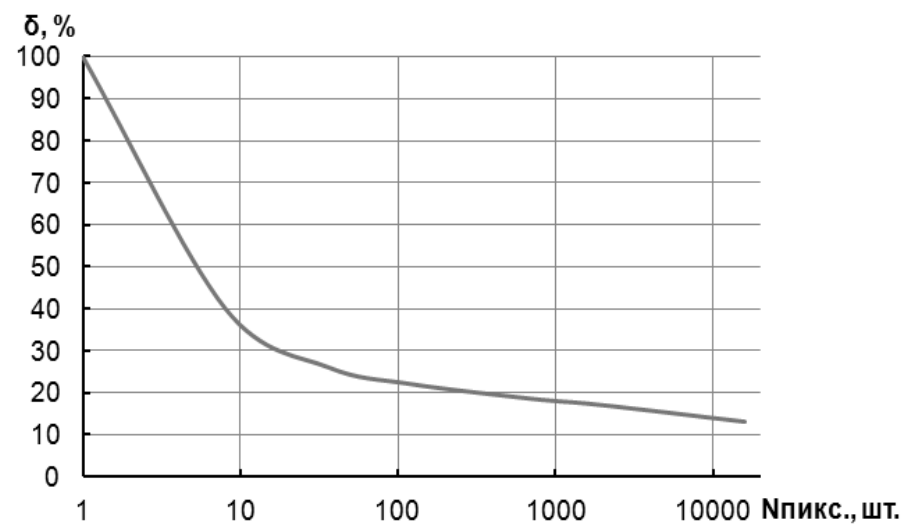

Рис. 1. График зависимости минимальной доли засвеченных пикселей изображения от общего числа элементов, участвующих в построении изображения объекта, приводящей к его нераспознаванию засвеченных пикселей в формируемом изображении. Полученные результаты представлены на рис.1.

В рамках модели установлено, что при применении стандартных корреляционных алгоритмов библиотек компьютер-ного зрения при засветке порядка $30 \%$ от общего количества пикселей, участвующих в построении изображения детектируемого объекта, происходит срыв его распознавания [4].

Расчет влияния внеполевой засветки на ОЭС на основе МФПУ - чрезвычайно сложная задача, зависящая от множества факторов [2, 3], которая в настоящее время мало изучена, однако даже простой анализ, приведенный выше, показывает, что эта проблема представляет большой интерес.

\section{Литература}

[1] С.В. Асанов и др. // Оптический журнал, 2012. Т. 79, вып. 9. С. 23-29.

[2] Н.И. Павлов, Ю.А. Резунков. // Оптический журнал, 2021. Т. 88, вып.1. С. 37-43.

[3] Н.И. Павлов, Ю.А. Резунков. // Квантовая электроника, 2020. Т. 50, вып. 12. С. 1160-1166.

[4] М.В. Сахаров, Д.С. Конради. // Вестник НПО им.С.А, Лавочкина, 2020. №1(47). С. 29-35.

[5] М.В. Сахаров и др. // Изв. высших учебных заведений.Физика, 2013. Т. 56, №9-2. С. 98-101. 